Прокофьев К.Г.

\title{
РОЛЬ ПОЛИЦИИ В РЕАЛИЗАЦИИ АДМИНИСТРАТИВНОЙ ОТВЕТСТВЕННОСТИ ЗА НАРУШЕНИЕ ЗАКОНОДАТЕЛЬСТВА О СОБРАНИЯХ, МИТИНГАХ, ДЕМОНСТРАЦИЯХ, ШЕСТВИЯХ И ПИКЕТИРОВАНИИ
}

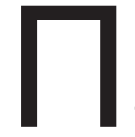

раво на свободу мирных собраний, будучи общепризнанной демократической ценностью, нуждается в особой защите, поскольку с его помощью достигается формирование и выражение мнений и требований разнообразных политических сил и общественных групп и тем самым создаются необходимые предпосылки для обеспечения обратной связи граждан (их объединений) с институтами публичной власти. Поэтому - даже принимая во внимание то обстоятельство, что реализация данного права объективно связана с очевидными рисками, опасность наступления которых существенно возрастает в случае неисполнения организаторами публичных мероприятий своих обязанностей. Следует отметить, что государство не должно, несмотря на преследуемые превентивные цели, вводить такие санкции за вред, причиненный участниками публичного мероприятия, которые заведомо ставили бы его организатора в положение стороны, несущей гражданско-правовую ответственность за действия других лиц вне зависимости от наличия (отсутствия) его вины в причинении вреда.

Вызвавшие большой общественный резонанс события на улицах и площадях ряда крупнейших городов нашей страны в 2011 -2012 гг. с особой силой высветили системную проблему реализации на практике права граждан собираться мирно и без оружия, как это предусмотрено статьей 31 Конституции Российской Федерации. Вопреки широко распространенному мнению эта проблема, как представляется, не имеет четко сфокусированной политической модальности.

Под «неправомерное воздействие» сотрудников полиции, стремящихся не допустить проведения публичного мероприятия, попадают порой не только радикальные оппозиционеры, но, и просто случайные прохожие.

Дежурно отрицая фракты неадекватного применения силы, представители МВД России и других органов власти обычно объясняют подобные действия необходимостью пресечения неких «несанкционированных» или «несогласованных» манифестаций. Такая позиция в лучшем случае указывает на весьма субъективное понимание должностными лицами положений ст. 31 Конституции Российской Федерации, а также Федерального закона РФ от 19 июня 2004 г. «O собраниях, митингах, демонстрациях, шествиях и пикетированиях» ${ }^{1}$.

Но прежде чем продолжить обсуждение данной проблемы, требующей самого пристального внимания, позволим себе обратиться к истории, так как нам представляется это целесообразным и важным. Итак, если говорить о праве граждан как о таковом на проведение публичных мероприятий, нужно отметить, что впервые механизмы реализации данного права были закреплены в Именном высочайшем Указе Правительствующему сенату 12 октября 1905 г. «Об установлении временных мер в дополнение действующих постановле-

${ }^{1}$ См.: Собрание законодательства РФ. - 2004. - № 25. Ст. 2485. 
ниях о собраниях» ${ }^{2}$, Именном высочайшем Указе Правительствующему сенату от 4 марта 1906 г. «О временных правилах и собраниях» ${ }^{3}$, постановлении временного Правительства от 12 апреля 1917 г. «О собраниях и союзах» 4 .

Так, в Конституции (основной закон) РСФСР от 10 июля 1918 г. говорилось о том, что в целях обеспечения за трудящимися действительной свободы собраний РСФСР, признавая право граждан Советской Республики свободно устраивать собрания, митинги, шествия и т.п., предоставляются в распоряжение рабочего класса и крестьянской бедноты все пригодные для устройства народных собраний помещения с обстановкой, освещением и отоплением (п. 15). Конституция РСФСР, утвержденная постановлением XII Всероссийского съезда советов от 11 мая 1925 г., также установила: в целях обеспечения за трудящимися действительной свободы собраний РСФСР, признавая право граждан Советской Республики свободно устраивать собрания, митинги, шествия и т.п., предоставить в распоряжение рабочего класса и крестьянства все пригодные для устройства народных собраний помещения (п. 6).

Конституция (основной закон) СССР от 5 декабря 1936 г. в соответствии с интересами трудящихся и в целях укрепления социалистического строя гарантировала гражданам свободу собраний и митингов; свободу уличных шествий и демонстраций (ст. 125).

Конституция (основной закон) СССР от 7 октября 1977 г. в соответствии с интересами народа и в целях укрепления и развития социалистического строя гражданам СССР гарантировала свободы: слова, печати, собраний, митингов, уличных шествий и демонстраций. Осуществление

\footnotetext{
${ }^{2}$ См.: Собрание узаконений. - 1905. - № 187. - Ст. 1649.

${ }^{3}$ См.: Собрание узаконений. - 1906. - № 48. - Ст. 309.

${ }^{4}$ См.: Вестник Временного Правительства. - 1917. - № 35. - Ст. 81.
}

этих политических свобод обеспечивалось предоставлением трудящимся и их организациям общественных зданий, улиц и площадей, широким распространением информации, возможностью использования печати, телевидения и радио (ст. 50).

Конституция РСФСР от 12 апреля 1978 г., которая в начале 90-х годов XX в. трансформировалась в Конституцию Российской Федерации, определяла, что граждане Российской Федерации вправе собираться мирно и без оружия, проводить митинги, уличные шествия, демонстрации и пикетирование при условии предварительного уведомления властей (ст. 49).

В связи с вышеизложенным нужно отметить, что проблемы, касающиеся организации и проведения публичных мероприятий, нашли свое отражение в трудах ученых конца XIX в. начала XX в. В частности, к данной проблематике обращались такие ученые, как В.Ф. Дерюжинский, И.Т. Тарасов, В.В. Ивановский и др. ${ }^{5}$ Они исследовали специфику публичных мероприятий, при этом нередко обращались к опыту Западной Европы, поскольку законодательство Российской империи в этом вопросе существенно отставало.

И.И. Ивановский детально изучил особенности административно-правового регулирования порядка организации и проведения публичных мероприятий в зарубежных государствах, на основании чего ввел в оборот такой термин как «полиция собраний» ${ }^{6}$.

Многие идеи и положения ученых-административистов Российской империи остались не востребованными и не получили своей дальнейшей теоретической оценки.

Целью публичных мероприятий является доведение до сведения органов государственной власти и всего общества в

\footnotetext{
${ }^{5}$ См.: Дерюжинский В.Ф. Полицейское право. - СПб., 1908. - С. 64-115; Тарасов И.Т. Полицейское право. - М., 1891. - С. 133; Ивановский В.В. Учебник административного права. Полицейское право. Право внутреннего управления. - Казань, 1911. - С. 186.

${ }^{6}$ См.: Ивановский В.В. Там же. - С. 193.
} 
целом коллективного согласия или несогласия с внутренней и внешней политикой государства, с действиями его отдельных органов и должностных лиц, а также с позицией или действиями каких-либо общественно-политических сил. Проведение гражданами собраний, митингов, демонстраций, шествий и пикетирований является важным демократическим завоеванием.

Право граждан на проведение публичных мероприятий относится к числу неотъемлемых и основополагающих функциональных элементов демократического общества ${ }^{7}$. По мнению британского ученого-административиста А.В. Дайси «право собираться есть не что иное, как результат взгляда судов на индивидуальную свободу личности и индивидуальную свободу слова» ${ }^{8}$.

На протяжении всей истории развития советского конституционного законодательства и до настоящего момента право на свободу собраний, митингов, шествий и демонстраций (1905 г.) $)^{9}$ обрело свою общественно-политическую самодостаточность, продолжая и далее эволюционировать.

Справедливости ради нужно заметить, что «двигателем» эволюции этого права являются все те же так называемые публичные мероприятия: собрания митинги, шествия, так как в ходе данных публичных мероприятий осуществляется защита гражданами своих субъективных прав.

Посредством публичных мероприятий граждане могут привлечь внимание органов власти к важнейшим социальным проблемам. Кроме того, публичные мероприятия служат средством реализации и удовлетворения гражданами не только их

\footnotetext{
${ }^{7}$ См.: Лейбо Ю.И., Толстопятенко Г.П., Экштайн К.А. Права и свободы человека и гражданина. - М., 2000. - С. 188.

${ }^{8}$ Дайси А.В. Основы государственного права Англии. M., 1907. - C. 308.

${ }^{9}$ См.: Колосов И.С. Закрепление права на проведение собраний, митингов и демонстраций, шествий и пикетирования в Конституциях РСФСР и СССР // Труды юридического факультета Ставропольского государственного университета. - Ставрополь, 2005. - С. 33.
}

социально-политических, но и культурных прав. Через свободу манифестаций осуществляется связь между гражданином и государством - это фрорма непосредственной демократии, при помощи манифестаций осуществляется и поддержка гражданами действий государственных и общественных органов и организаций, а также отдельных политических деятелей и должностных лиц ${ }^{10}$.

В этой связи обеспечение права на мирные собрания митинги, шествия, демонстрации и пикетирования следует рассматривать как важную гарантию участия граждан в управлении делами демократического государства.

Как уже отмечалось, демонстрации, митинги, шествия, пикетирования и другие публичные мероприятия играют важную роль в деле построения гражданского общества и правового государства, тем не менее, данные мероприятия проводятся в режиме, определенном законом.

Согласно Конституции России (ст. 55), а также действующему законодательству право граждан на проведение публичных мероприятий может быть ограничено законом, так как, на наш взгляд, реальной угрозой стабильности демократического государства и всего общества является злоупотребление свободой мирных собраний и, в частности, использование ее для выдвижения антиконституционных экстремистских лозунгов, для провоцирования общественных беспорядков и иного посягательства на права и интересы граждан ${ }^{11}$.

Государство вынуждено принять соответствующие меры, чтобы оградить себя и своих граждан от этой опасности.

Для обеспечения правопорядка при поведении публичных мероприятий на-

\footnotetext{
${ }^{10}$ См.: Дмитриев Ю.А. Свобода манифестаций в СССР. M., 1991. - C. 32-33.

${ }^{11}$ См.: Коптев Н.В. Административно-правовая охрана порядка организации и проведения публичных мероприятий: Дис. ... канд. юрид. наук. - М., 2001. - С. 34.
} 


\section{Полицейская деятельность 2 • 2014}

правлено действующее законодательство. Так, подпунктом «а» п. 1 ст. 2 Федерального закона от 8 июня 2012 г. № 65-Ф3 ч. ст. 5 Федерального закона «О собраниях, митингах, демонстрациях, шествиях и пикетированиях» ${ }^{12}$ дополнена п. 1.1, согласно которому не может быть организатором публичного мероприятия лицо, имеющее неснятую или непогашенную судимость за совершение умышленного преступления против основ конституционного строя и безопасности государства или преступления против общественной безопасности и общественного порядка либо два и более раза привлекавшееся к административной ответственности за административные правонарушения, предусмотренные статьями 5.38, 19.3, 20.1- 20.3, 20.18 и 20.29 КоАП Российской Федерации, в течение срока, когда лицо считается подвергнутым административному наказанию.

Предъявление к инициаторам проведения собраний, митингов, демонстраций, шествий и пикетирований особых требований обусловлено тем, что одной из основных целей любого публичного мероприятия является привлечение общественного внимания и, следовательно, оно объективно затрагивает интересы значительного числа граждан (как принимающих в публичном мероприятии непосредственное участие, так и претерпевающих те или иные последствия его проведения), чем создается потенциальная опасность нарушения общественного порядка. Исходя из этого федеральный законодатель ввел запрет в течение определенного срока быть организатором публичного мероприятия для лиц, неоднократно (два и более раза) привлекавшихся к административной ответственности за следующие предусмотренные Кодексом Российской Федерации об административных правонарушениях деяния, характер, а также неоднократ-

${ }^{12}$ См.: Собрание законодательства РФ. - 2004. - № 25. Ст. 2485. ность совершения которых позволяют усомниться в возможности таких лиц организовать и, главное, провести мирное публичное мероприятие с соблюдением установленного законом порядка: нарушение законодательства о собраниях, митингах, демонстрациях, шествиях и пикетировании (ст. 5.38); неповиновение законному распоряжению сотрудника полиции, военнослужащего, сотрудника органов по контролю за оборотом наркотических средств и психотропных веществ, сотрудника органов фредеральной службы безопасности, сотрудника органов государственной охраны, сотрудника органов, уполномоченных на осуществление функций по контролю и надзору в сфрере миграции, либо сотрудника органа или учреждения уголовно-исполнительной системы (ст. 19.3); мелкое хулиганство (ст. 20.1); нарушение установленного порядка организации либо проведения собрания, митинга, демонстрации, шествия или пикетирования (ст. 20.2); организация массового одновременного пребывания и (или) передвижения граждан в общественных местах, повлекших нарушение общественного порядка (ст. 20.2.2); пропаганда и публичное демонстрирование нацистской атрибутики или символики либо публичное демонстрирование атрибутики или символики экстремистских организаций (ст. 20.3); блокирование транспортных коммуникаций (ст. 20.18); производство и распространение экстремистских материалов (ст. 20.29).

Административная ответственность за некоторые из упомянутых административных правонарушений, как вытекает из статей 2.1, 2.10, 19.3, 20.2, 20.2.2, 20,3, 20.18 и 20,29 КоАП Российской Федерации, может применяться как к гражданам, так и к политическим партиям, общественным объединениям и религиозным объединениям (их региональным отделениям и иным структурным подразделениям), обладающим статусом юридического лица. Однако запрет, введенный в отношении лиц, совершивших 
такие административные правонарушения, подпунктом «а» п. 1 ст. 2 Федерального закона от 8 июня 2012 г. № 65-Ф3, как следует из взаимосвязанных положений ч. 1 и пунктов 1.1 и части 2 ст. 5 Федерального закона «О собраниях, митингах, демонстрациях, шествиях и пикетированиях», может быть распространен исключительно на граждан Российской Федерации, достигших к тому же определенного возраста, поскольку в силу прямого указания закона политическая партия, другое общественное объединение и религиозное объединение, их региональные отделения и иные структурные подразделения не могут быть организатором публичного мероприятия только в случае, если их деятельность приостановлена или запрещена либо если они ликвидированы в установленном законом порядке.

Также необходимо сказать, что, согласно Федеральному конституционному закону РФ от 30 мая 2001 г. «О чрезвычайном положении» ${ }^{13}$ Указом Президента Российской Федерации о введении чрезвычайного положения на период действия чрезвычайного положения может предусматриваться запрещение или ограничение проведения собраний, митингов и демонстраций, шествий и пикетирования, а также иных массовых мероприятий (ст. 11 данного закона).

В соответствии с Федеральным конституционным законом РФ от 30 января 2002 г. "О военном положении» ${ }^{14}$ на основании указов Президента Российской Федерации на территории, на которой введено военное положение, запрещается или ограничивается проведение собраний, митингов и демонстраций, шествий и пикетирования, а также иные массовые мероприятия (ст. 7 данного закона).

Публичные мероприятия в России представляют собой сложные и очень зна-

\footnotetext{
${ }^{13}$ См.: Собрание законодательства РФ. - 2001. - № 23. Ст. 2277.

${ }^{14}$ См.: Собрание законодательства РФ. - 2002. - № 5. Ст. 375.
}

чимые социальные явления. Тем не менее, мы обращаем ваше внимание на то, что все еще отсутствуют общепризнанное определение понятия «публичные мероприятия» и единая классификация ${ }^{15}$ таковых, поскольку они далеко не однородны.

Как отмечает В.В. Ларин, публичное мероприятие - это организованное действие (совокупность действий или явлений социальной жизни) с участием больших масс людей, совершающееся в интересах трудящихся с целью удовлетворения их политических, духовных, фризических и других потребностей, являющееся фрормой реализации их прав и свобод, а также формой социального общения между людьми и способом выработки единства установок личности, коллектива, общества в целом ${ }^{16}$.

На наш взгляд, В.В. Ларин верно определил границы этого социального явления, позволяющие отличить его от других явлений, предложив основные признаки публичного мероприятия: наличие больших масс людей; организованность действия (действий); наличие цели (целей). Нам представляется, к данным признакам следует также присоединить такой признак как публичность.

В.Ф. Дерюжинский отмечал, что публичное собрание - собрание, доступное неопределенному числу лиц, или хотя бы определенному числу лиц, но лично не заинтересованных устроителем собрания. Собрания же, в которых участвуют одни члены законно существующего общества или союза, и посторонние лица не присутствуют, он относит к публичным ${ }^{17}$.

Следовательно, опираясь на вышеизложенное, считаем необходимым обратить внимание на то, что массовое мероприятие будет всегда являться публичным.

\footnotetext{
${ }^{15}$ См.: Коптев Н.В.Указ. соч. - С. 35.

${ }^{16}$ См.: Ларин В.В. Понятие административно-правовой охраны общественного порядка при проведении массовых мероприятий // Теория и практика совершенствования охраны общественного порядка. - М., 1985. - C.54.

${ }^{17}$ См.: Дерюжсинский В.Ф. Указ. соч. - С. 102.
} 


\section{Полицейская деятельность 2 • 2014}

Н.В. Караханов публичное мероприятие определяет как организованную, санкционированную или несанкционированную форму активных действий больших масс людей (групп), которые нацелены на выражение воли, защиту своих прав и свобод, законных интересов, на удовлетворение потребностей в экономической, политической, социально-культурной и других материальных и духовных сфрерах ${ }^{18}$.

Д.К. Нечевин говорит о том, что публичное мероприятие представляет собой организованную фрорму активных действий большого числа граждан, осуществляемых в общественных местах, в целях выражения коллективного мнения по различным вопросам общественной жизни, духовного и эмоционального удовлетворения ${ }^{19}$.

В приведенных определениях внимание акцентировано на организационноправовых аспектах публичных мероприятий. Данные определения содержат прямое указание на обязательную организацию или санкционирование проведения активных действий компетентными государственными органами или общественными организациями. А.М. Алоян и В.И. Эглит 20 указывают и на то обстоятельство, что в некоторых случаях целенаправленные и правомерные действия больших групп людей осуществляются на основании обычаев - в первую очередь это религиозные праздники, в которых в силу различных причин принимают участие и лица, далекие от религии. Однако и здесь также не в полной мере выявлены сущность и содер-

\footnotetext{
${ }^{18}$ См.: Караханов Н.В. Управление горрайорганами внутренних дел при проведении массовых мероприятий. М., 1992. - C. 6.

${ }^{19}$ См.: Нечевин Д.К. Организация деятельности органов внутренних дел по обеспечению правопорядка при проведении массовых мероприятий // Предупреждение преступности и обеспечение безопасности в городах. - М., 2001. - C. 90 .

${ }^{20}$ См.: Алоян А.М., Эглит В.И. Правовое регулирование охраны общественного порядка при проведении 15 массовых мероприятий // Административно-правовые проблемы охраны общественного порядка. - М., 1987.
}

жание этого сложного и многоаспектного социального явления.

Н.В. Коптев отмечает, что публичное мероприятие - это организованная санкционированная или несанкционированная форма активных публичных действий больших масс (групп) людей в общественных местах в целях выражения их воли, защиты своих прав, свобод, законных интересов удовлетворения потребностей в экономической, политической социально-культурной других материальных и духовных сфрерах ${ }^{21}$.

Данное определение содержит отмеченные выше основные признаки публичного мероприятия, но главное здесь заключается в том, что действия масс или групп преломляются, прежде всего, через категорию публичности, социальной активности, под которой понимается деятельное отношение людей к жизни общества, в котором они выступают как субъекты и носители социально значимых норм, идеалов, интересов и других человеческих ценностей.

В целях более глубокого исследования сущности, понятия и содержания публичных мероприятий необходимо произвести их классификацию по различным основаниям. Классификация есть расположение изучаемых явлений на основании существенных признаков сходства и различия, «согласно внутренне присущей им последовательности» ${ }^{22}$.

В нашем случае - это публичные мероприятия, которые весьма многочисленны и разнообразны. Отнесение их к той или иной группе помогает правильно понять социальное назначение и место каждого из них в классификационной системе. Наличие достаточно полной классификации публичных мероприятий имеет не только теоретическое, но и большое практическое значение, в том числе для дальнейшего совершенствования работы государ-

\footnotetext{
${ }^{21}$ См.: Коптев Н.В. Указ. соч. - С. 28.

${ }^{22}$ См.: Теория государства и права / Под ред. А.М. Васильева. - М., 1983. - С. 74.
} 
ственных органов, в частности, органов внутренних дел по обеспечению законности и общественного порядка при проведении публичных мероприятий. Достаточно продуктивной является точка зрения В.Т. Ковалева относительно разграничения публичных мероприятий. По его мнению основным критерием, позволяющим провести такое разграничение, является функция, свойственная каждой разновидности публичных мероприятий ${ }^{23}$.

Изучение специальной литературы и нормативных актов показало, что публичные мероприятия классифицируются преимущественно крупными блоками - в общественно-политические, культурномассовые и др., и только в отдельных работах предпринимается попытка раскрыть содержание этих блоков ${ }^{24}$. Анализ различных точек зрения по вопросу о классификации публичных мероприятий позволяет сделать определенные выводы.

Основная сложность классификации публичных мероприятий состоит в том, что обстоятельств, влияющих на их содержание и характеристику, очень много. Необходимо помнить, что обстоятельства, влияющие на их содержание и оценку, нельзя рассматривать в отрыве друг от друга; если это не соблюдается, то классифрикация страдает определенной односторонностью. Помимо этого крайне важно, чтобы каждая классификация имела бы реальное основание и научно-практическое значение. Классификация публичных мероприятий отчасти носит условный характер, но не может быть произвольной и случайной. Она должна основываться на существенных признаках и специфических особенностях, коренящихся в существе классифицируемого и систематизируемого административно-правового материала.

\footnotetext{
${ }^{23}$ См.: Ковалев В.T. Свобода собраний, митингов, шествий демонстраций: проблемы законодательного регулирования // Самоуправление: теория и практика. - М., 1991.-С. 59.

${ }^{24}$ См.: Алоян А.М., Эглит В.И. Указ. соч. - С. 19.
}

Но, как нам представляется, дело не в поиске все новых и новых критериев классификации публичных мероприятий, а в отборе тех из них, которые позволяют наиболее четко отграничить и, следовательно, изучить каждую группу публичных мероприятий.

По О.Э. Лейсту «классификация - способ обнаружения существенных качеств подразделений системы, от которых зависят другие производные от них признаки каждого из элементов подразделения» ${ }^{25}$. В практической плоскости классификация обеспечивает научный подход в выборе форм и методов административно-правового регулирования в сфрере охраны общественного порядка при проведении того или иного публичного мероприятия.

В зависимости от характера собраний публичные мероприятия подразделяются на толпу - случайное собрание, сходку - нелегальное собрание, собственно собрание - если оно устроено легально лицами, живущими в определенной местности, и съезд или конференцию - если собрание устраивалось лицами, живущими в разных местностях ${ }^{26}$.

Д.К. Нечевин классифицирует публичные мероприятия по следующим критериям: по значимости: международные, общегосударственные, региональные и местные; по месту проведения: мероприятия, проводимые в зданиях, сооружениях, спортивных комплексах, на открытой местности; по периодичности проведения: разовые, повторяющиеся, повседневные; по возможности участия: общедоступные, с ограничением числа участников; по составу участников: массовые мероприятия могут быть дифференцированы на мероприятия со смешанным составом участников, либо представлены участниками, имеющи-

\footnotetext{
${ }^{25}$ Лейст O.Э. Санкции и ответственность по советскому праву. - М., 1981. - С. 61.

${ }^{26}$ См.: Евтихиев А.Ф. Основы советского административного права. - Харьков, 1925. - С. 219.
} 
ми особый социальный статус; по содержанию: общественно-политические; культурно-зрелищные; спортивно-массовые; религиозные (похоронные); по масштабу: международные, общефедеральные, региональные и муниципального значения ${ }^{27}$.

Публичные мероприятия могут быть классифицированы в зависимости от организационно-правовой формы.

В зависимости от вида публичного мероприятия арсенал административно-правовых средств охраны общественного порядка при их проведении различен. Кроме того, как отмечает И.С. Полянская, «любое публичное мероприятие, независимо от целей должно быть мирным, то есть не носить насильственного или подстрекательского характера» ${ }^{28}$.

В.В. Ивановский в начале $\mathrm{XX}$ в. говорил о том, что если открытие собрания допущено, то оно должно быть закрыто полицейским чиновником в следующих случаях: когда собрание отклоняется от предмета его занятий; когда в собрании высказываются суждения, возбуждающие вражду одной части населения против другой; когда в собрании производятся неразрешенные денежные сборы; когда в нем окажутся лица, в собрание не допускаемые, как лица вооруженные, военные нижние чины, а если собрание политическое, то и все лица военного звания, учащиеся низших и средних учебных заведений; когда будет нарушен порядок собрания мятежными возглавиями, либо заявлениями, восхваляющими или оправдывающими преступление, заявлениями, возбуждающими призывы к насилию или неповиновению к властям, или заявлени-

27 См.: Деятельность нарядов милиции по охране общественного порядка и безопасности в обычных и особых условиях. - М., 1996. - С. 3.

${ }^{28}$ См.: Полянская И.С. Конституционно-правовое регулирование права граждан Российской Федерации на проведение собраний, митингов и демонстраций, шествий и пикетирования: Автореф. дис. ... канд. юрид. наук. - М., 2005. - C. 17. ями, угрожающими общественному спокойствию и безопасности ${ }^{29}$.

Проведенный анализ публичных мероприятий, состоявшихся в 2012 году, свидетельствует о снижении количества общественно-политических мероприятий по сравнению с 2011 г. на 14\% (в прошлом году состоялось более 62 тыс. публичных мероприятий, 2011 - более 72 тыс.). При этом характерно, что наибольшая доля публичных мероприятий пришлась на первое полугодие, что напрямую связано с прошедшими избирательными кампаниями по выборам депутатов Государственной Думы Федерального Собрания Российской Федерации 6 созыва (декабрь 2011 г.) и Президента Российской Федерации (4 марта 2012 г.).

\section{Диаграмма № 1} Количество общественно-политических
мероприятий за 2012 и 2011 г.г.

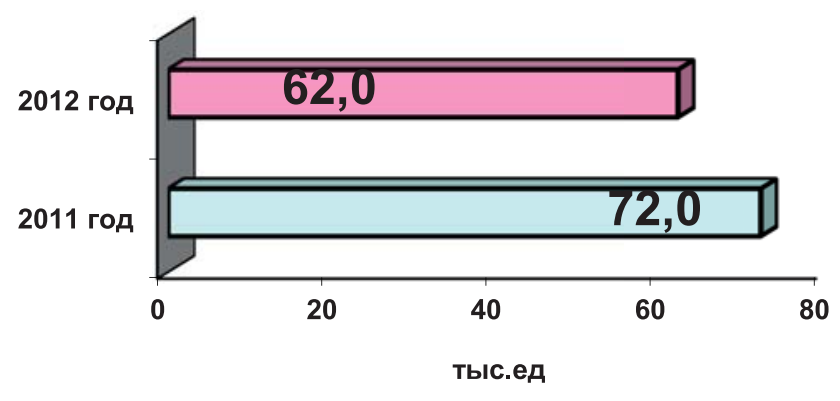

В обеспечении общественного порядка и безопасности при проведении публичных и массовых мероприятий в 2012 г. задействовалось около 550 тыс. сотрудников полиции (+16\%, АППГ - свыше 460 тыс.). 
Диаграмма № 2

Количество общественно-политических мероприятий за 2012 и 2011 г.г. по федеральным округам

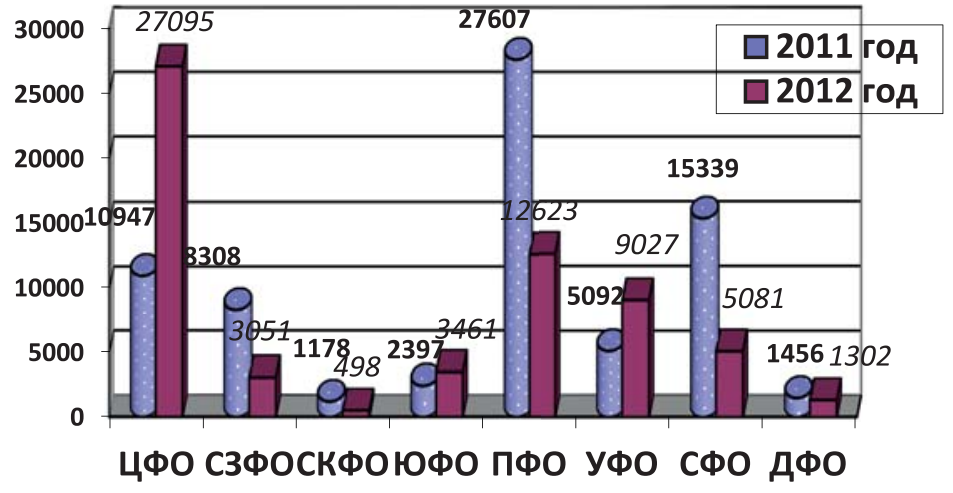

Наибольшее количество публичных мероприятий зафиксировано в Центральном (27095), Приволжском (12623) и Уральском (9027) федеральных округах.

По количеству общественно-политических мероприятий среди регионов Российской Федерации лидируют: г. Москва 22870 мероприятий, Свердловская область - 6882, Самарская область - 4849 и Республика Башкортостан - 3214 (в г. СанктПетербурге и Ленинградской области состоялось 2012 публичных мероприятий).

Несмотря на уменьшение количества публичных мероприятий, отмечается значительный рост их участников. Всего в анализируемый период в публичных мероприятиях приняло участие свыше 8,7 млн. чел. (8 714 894), что на $73,2 \%$ больше, чем в аналогичном периоде 2011 г. (свыше 5 млн чел.).
Наибольшее количество участников публичных мероприятий отмечено в Южном (более 3,4 млн чел.), Центральном (более 1,8 млн чел.) и Уральском (более 1,3 млн чел.) федеральных округах.

По количеству участников публичных мероприятий среди регионов Российской Федерации лидируют: Краснодарский край (3 328085 чел.), г. Москва (879 347 чел.), Тюменская (828 803 чел.) и Московская области (417 778 чел.) (в 2. Санкт Петербурге и Ленинградской области этот показатель составил 114056 чел.).

Число публичных мероприятий, несогласованных с органами исполнительной власти, снизилось на $11,6 \%$ и составило 586 (2011 2. - 663). На 11,5\% снизилось количество фрактов блокирования транспортных коммуникаций (с 26 - в 2011 году до 23 - в 2012 году). Наиболее характерна данная фрорма протестных действий для Республики Дагестан, где зафиксировано 17 из 23 подобных случаев.

Диаграмма № 3

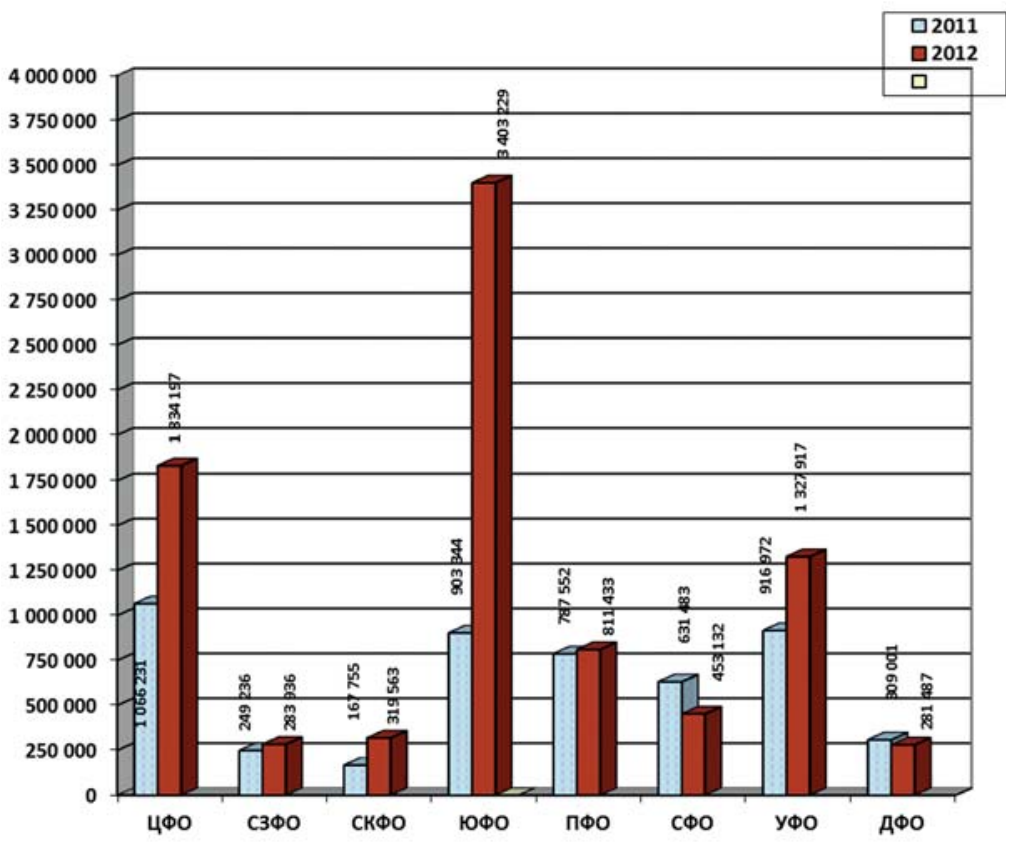


Диаграмма № 4

\section{Количество несогласованных публичных мероприятий за \\ 2012 и 2011 г.г. по федеральным округам}

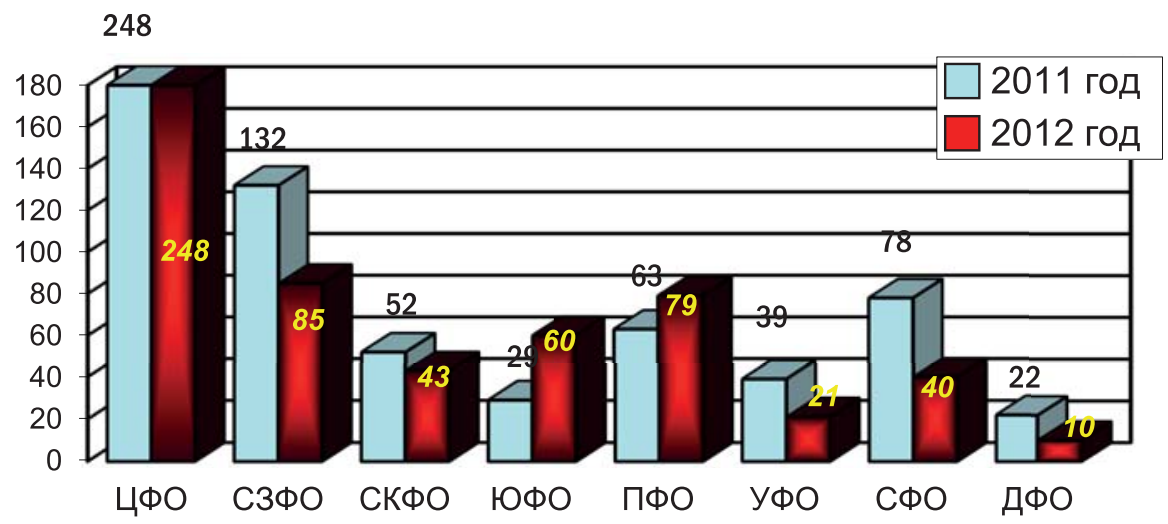

ющих их организацию и проведение ${ }^{30}$.

Понятно, что участие граждан в различных публичных мероприятиях - одна из фрорм реализации их прав и свобод, закрепленная в Конституции Российской Федерации. В процессе участия В таких мероприятиях граждане имеют возможность проявить личную и групповую инициативу, выразить отношение к тому или иному политическому, социальному или другому событию,

По количеству несогласованных публичных мероприятий среди регионов Российской Федерации лидируют: г. Москва - 204, Краснодарский край -44 , Калининградская область - 40, г. СанктПетербург и Ленинградская область и Республика Башкортостан - по 34 соответственно.

Число лиц, принявших участие в несогласованных мероприятиях, уменьшилось на $33 \%$ (более 28 тыс. чел. - в 2012, АППГ-около 43 тыс. чел.).

Что в первую очередь является результатом профилактического действия изменений, внесенных в законодательство, регламентирующее проведение публичных мероприятий.

Классификации публичных мероприятий имеет важное практическое для органов внутренних дел в сфере организации охраны общественного порядка при проведении собраний митингов, демонстраций, шествий и пикетирования. Как отмечает Д.К. Нечевин, «классификация массовых мероприятий по сходным признакам дает общее представление об их широком спектре, что, в свою очередь, предполагает и многообразие правовых норм, регламентиру- явлению, потребовать от компетентных органов решения тех или иных вопросов ${ }^{31}$.

Дальнейшее развитие фрорм участия граждан в публичных мероприятиях в условиях демократии требует более детального изучения и уточнения понятийно-терминологического аспекта проблемы публичных мероприятий, что позволит совершенствовать правовые акты, регулирующие общественные отношения во время подготовки и проведения этих мероприятий.

Демократизация общества создает условия для поднятия общественной активности граждан, в том числе посредством участия в публичных мероприятиях, что открывает возможность для активизации количественного фрактора волеизъявления граждан и создания новых форм ее выражения. О нарастании общественной активности говорит статистика.

\footnotetext{
${ }^{30}$ См.: Нечевин Д.К. Указ соч. - С. 92.

${ }^{31}$ См.: Коптев Н.В. Указ. соч. - С. 29; Голованев И.В. Правовые основы и организация охраны общественного порядка при проведении собраний, митингов, уличных шествий и демонстраций: Автореф. дис. ... канд. юрид. наук. - М., 1992. - С. 13; Балтага Д.А. Политические свободы собраний, митингов, уличных шествий и демонстраций и их реализация в деятельности органов внутренних дел: Дис. ... канд. юрид. наук. - М., 1993. - С. 19 и др.
} 
В ходе исследования выявлено, что в период с 1986-1988 гг. в ряде городов и регионов страны состоялось более 250 многолюдных митингов, шествий и демонстраций. При этом некоторые из них носили националистический, экстремистский характер ${ }^{32}$.

В 1998 г. самодеятельными организациями было проведено 2995 митингов, уличных шествий и демонстраций, а в 1999 г. таких мероприятий зарегистрировано 5382. Число указанных мероприятий стремительно растет ${ }^{33}$.

С 2000 по 2013 гг. на территории Российской Федерации было проведено 3856 несанкционированных массовых акций, в которых приняли участие 367,5 тыс. чел. Наибольшее их количество отмечалось в Кировской области (953 акции), г. Москве (192) и Иркутской области (130). Наибольшее количество участников акций зарегистрировано в Республике Дагестан (26,3 тыс. чел.), в г. Санкт-Петербурге $(13,3)$, Чеченской Республике $(13,3)$ и Приморском крае $(11,5)$. За отчетный период было проведено около 1978 забастовок, в которых приняли участие 67,5 тыс. человек. Наибольшее количество участников забастовок отмечалось в Кировской (16,9 тыс. чел.), Иркутской $(4,7)$ и Курганской $(4,6)$ областях.

Состоялось 286 голодовок. В них приняли участие 5,7 тыс. чел. Наибольшее количество участников голодовок зарегистрировано в Ростовской (566 чел.), Томской (531), Иркутской (465) областях и Приморском Крае (430). В период с 2000 по 2006 гг. было проведено 499 пикетирований. В них приняли участие 33,6 тыс. чел. Наибольшее количество участников пикетирований отмечалось в г. Москве $(4,4$ тыс. чел.), Карачаево-Черкесской Республике $(3,1)$ и Ивановской области $(1,5)$.

\footnotetext{
32 См.: Веремеенко И., Воробъев В., Якимов А. Митинги, демонстрации, собрания // Социалистическая законность. -1989 . - № 6. - С. 52.

${ }^{33}$ См.: Коптев Н.В. Указ. соч. - С. 25.
}

Граждане России провели 415 блокирований дорог, в них приняли участие 85,2 тыс. чел. Наибольшее количество участников блокирований отмечалось в Республике Дагестан (9,3 тыс. чел.), Чеченской Республике (5), Пермской $(4,4)$ и Ивановской $(3,4)$ областях.

В стране было проведено 678 несанкционированных митингов, шествий, собраний, демонстраций, в которых приняли участие 175,5 тыс. чел. Наибольшую активность проявили жители Республики Дагестан (17 тыс. чел.), г. Санкт-Петербурга $(13,3)$, Республики Башкортостан (10) и Чеченской Республики $(9,7)$.

Статистика о проведении санкционированных массовых акций на территории Российской Федерации в МВД России не предусмотрена.

Как уже нами отмечалось, в период с 8 января по 31 августа 2007 г. в 73 субъектах Российской Федерации состоялись 1292 акции протеста, в них приняли участие 317,5 тыс. чел. Наибольшее количество акций протеста состоялось в Москве (66 - 3,1 тыс. чел.), Санкт-ПетербургеиЛенинградскойобласти(52-3,6тыс.чел.), Московской (46 - 7,2 тыс. чел.) и Новосибирской (42 - 5,3 тыс. чел.) областях.

В структуре массовых акций преобладают митинги (963), пикетирования (254), блокирования автомагистралей, дорог и улиц (53), собрания (13) и шествия (7). Предотвращены 7 попыток перекрытия автомагистралей, дорог и улиц, связанных с повышением тарифов на услуги ЖКХ. Наибольшее количество акций блокирования состоялось в Амурской области (2 - 2,8 тыс. чел.). Для непосредственного участия в обеспечении общественного порядка и безопасности при массовых мероприятиях задействовались 46,8 тыс. сотрудников органов внутренних дел.

Итак, данная общественная активность (большое количество массовых акций протеста) вызывает объективную необходимость поддержать предложение о разработке единой формы статистической отчетности о публичных мероприятиях, 
проводимых в масштабах субъектов РФ и Российской Федерации в целом. Наличие таких сведений позволило бы изучать, анализировать, прогнозировать развитие публичных мероприятий и на этой основе разрабатывать научно обоснованные предложения и рекомендации, направленные на дальнейшее совершенствование деятельности органов внутренних дел, других государственных и общественных органов по обеспечению порядка организации и проведению данных мероприятий ${ }^{34}$.

Нужно признать, что изначально мирные публичные мероприятия могут таить в себе угрозу нарушения общественного порядка и спокойствия граждан. Так, за последние годы мирные по своей сути собрания, митинги и демонстрации, шествия и пикетирования превращались в страшные побоища, в ходе которых происходили массовые, групповые нарушения общественного порядка, создавалась реальная угроза жизни и здоровью граждан, а также их собственности.

В этой связи в целях охраны общественного порядка при проведении собраний, митингов и демонстраций, шествий и пикетирований необходим комплекс административно-правовых средств, что создало бы необходимый административно-правовой режим при проведении соответствующего публичного мероприятия.

Публичные мероприятия могут проводиться практически в любых общественных местах, хотя в некоторых случаях законом могут устанавливаться ограничения и запреты на проведение публичного мероприятия в том или ином месте. Согласно Федеральному закону РФ от 21 ноября 1995 г. «Об использовании атомной

\footnotetext{
${ }^{34}$ См.: Кравцчов В.М. Указ. соч. - С. 56; Казаков В.А. Охрана общественного порядка и безопасности во время проведения массовых мероприятий. - М., 1986. - С.11; Караханов Н.В. Указ. соч. - С. 34; Емельянов Б.М. Подготовка работников милиции к обеспечению охраны общественного порядка и общественной безопасности при проведении массовых мероприятий. - М., 1992. - С. 12 и др.
}

энергии» ${ }^{35}$ проведение несанкционированных собраний, митингов, демонстраций и других несанкционированных общественных мероприятий на территории ядерной установки или пункта хранения и в их санитарно-защитных зонах запрещается.

С определением места проведения публичного мероприятия на практике возникает ряд проблем.

Как следует из доклада Уполномоченного по правам человека в Российской Федерации $^{36}$ неоднозначным оказывается на практике и используемое в федеральном законе понятие «непосредственно прилегающая территория». Согласно закону «территории, непосредственно прилегающие к зданиям и другим объектам, - это земельные участки, границы которых определяются решениями органов исполнительной власти субъектов Российской Федерации или органов местного самоуправления в соответствии с нормативными правовыми актами, регулирующими отношения в сфере землеустройства, землепользования и градостроительства».

Отсутствие нормативного определения указанного понятия открывает простор для его произвольного толкования. К примеру, в столице Республики Бурятия г. Улан-Удэ для проведения публичных мероприятий закрыта площадь Советов, целиком рассматриваемая властями как непосредственно прилегающая к зданию Конституционного суда республики. Подобные примеры произвольного и необоснованно расширительного толкования понятия «непосредственно прилегающие территории» обнаруживаются в нормативных правовых актах и других субъектов Российской Федерации.

\footnotetext{
${ }^{35}$ См.: Собрание законодательства РФ. - 1995. - № 48. Ст. 4552.

${ }^{36}$ См.: О соблюдении на территории Российской Федерации конституционного права на мирные собрания: Специальный доклад Уполномоченного по правам человека в Российской Федерации // Российская газета от 28 июня 2007.
} 
В связи с этим следует подчеркнуть, что отсутствие нормативного определения понятия «непосредственно прилегающей территории» нарушает принцип правовой определенности, в результате чего, даже действуя с должной осмотрительностью, организаторы и участники публичных мероприятий не всегда могут в достаточной степени предусмотреть последствия своих действий.

Основы охраны общественного порядка при проведении собраний, митингов, демонстраций и пикетирования закреплены в целом ряде законодательных и иных нормативных правовых актах.

В частности, Федеральный закон РФ от 13 декабря 1996 г. «Об оружии» ${ }^{37}$ определяет, что на территории Российской Федерации запрещаются: ношение гражданами оружия при проведении митингов, уличных шествий, демонстраций, пикетирования и других массовых публичных мероприятий» (ст. 6).

Согласно Федеральному закону от 7 февраля 2011 г. «О полиции» ${ }^{38}$ сотруднику полиции запрещается применять специальные средства при пресечении незаконных собраний, митингов, демонстраций, шествий и пикетирований ненасильственного характера, которые не нарушают общественный порядок, работу транспорта, средств связи и организаций (ст. 22).

В этой связи в научной литературе правильно отмечается, что при осуществлении административно-правовой охраны общественного порядка в условиях массовых мероприятий крайне необходимо использование методов ненасильственного решения возможных конфлликтов, создание системы мер, способствующих согласованию интересов, выработке взаимоприемлемых, конструктивных решений ${ }^{39}$.

\footnotetext{
${ }^{37}$ См.: Собрание законодательства РФ. - 1996. - № 51. Ст. 5681.

${ }^{38}$ См.: Собрание законодательства РФ. - 2011. - № 7. Ст. 900 .

${ }^{39}$ См.: Кравияов В.М. Указ. соч. - С. 20.
}

Надо сказать, что несмотря на наличие целого ряда законодательных актов, предписания которых направлены на охрану общественного порядка при проведении публичных мероприятий, в настоящее время явно недостает нормативных правовых актов, регламентирующих непосредственно деятельность органов внутренних дел по вопросам, связанным с обеспечением охраны общественного порядка и общественной безопасности при проведении массовых публичных мероприятий.

В этой связи вполне целесообразно на основании Федерального закона РФ от 19 июня 2004 г. "О собраниях, митингах, демонстрациях, шествиях и пикетированиях» ${ }^{40}$ принять постановление правительства, в котором нужно будет четко определить правовые и организационные механизмы охраны общественного порядка при проведении собраний, митингов, демонстраций, шествий и пикетирования.

В данном документе необходимо определить силы, средства, участвующие в охране общественного порядка, механизмы взаимодействия между различными субъектами охраны общественного порядка, правовой статус оперативного штаба и др. Названные меры будут способствовать совершенствованию административно-правового регулирования охраны общественного порядка и права граждан при проведении собраний, митингов, демонстраций, шествий и пикетирований.

Практика охрана общественного порядка при проведении публичных мероприятий показала, что административная ответственность является одним из эффрективных средств предупреждения и пресечения различного рода правонарушений при проведении публичных мероприятий. В этой связи предписания КоАП оказались весьма востребованными. Следует также согласиться, что ответственность уста-

${ }^{40}$ См.: Собрание законодательства РФ. - 2004. - № 25. Ст. 2485. 
навливается прежде всего для стимулирования правомерного поведения, а не для применения наказания за неисполнение правовых норм ${ }^{41}$, т.е. главное назначение юридической ответственности в профилактическом, превентивном применении. Юридическая ответственность в ее личностно-психологическом смысле занимает самостоятельное место в структуре правосознания, это не только фракт понимания смысла предписаний правовых норм, но и выработка особого, активного отношения к ним, формирование установок правомерного поведения ${ }^{42}$.

В отличие от уголовной ответственности административная ответственность не влечет судимости, отличается меньшей тяжестью наказания и более коротким сроком давности. Все виды юридической ответственности имеют как общие, так и частные признаки. Что касается уголовной ответственности, то наиболее удачное определение данному виду юридической ответственности сорормулировано Н.А. Огурцовым и А.В. Наумовым. В частности, названные ученые отмечают, что уголовная ответственность представляет ту меру государственного принуждения, которая применяется в отношении лица, совершившего преступление, выступает для последнего в качестве неблагоприятного последствия за совершенное им преступление и означает отрицательную морально-политическую оценку преступления и личности преступника со стороны государства и общества ${ }^{43}$.

Административная ответственность - это мера административного принуждения, которая применяется за совершение административного правонарушения. Ад-

${ }^{41}$ См.: Рыбаков В.А. Позитивная юридическая ответственность (воспитательные аспекты). - Рязань, 1988. - С. 10.

42 См.: Юридическая психология / Под ред. Ю.В Чуфаровского. - М., 1998. - С. 244.

${ }^{43}$ См.: Огурияов Н.А., Наумов А.В. Понятие уголовной ответственности // Труды Высшей следственной школы МВД СССР. - Волгоград, 1969. - С. 159. министративная ответственность за нарушение законодательства о собраниях, демонстрациях, митингах шествиях и пикетировании реализуется в административно-процессуальном порядке путем применения санкций норм Особенной части КоАП РФ, а также предписаний законов субъектов Российской Федерации об административных правонарушениях.

Так, КоАП России содержит в себе ряд составов, предусматривающих административную ответственность за нарушения законодательства о собраниях, митингах, демонстрациях, шествиях и пикетированиях.

В частности, ст. 5.38 КоАП России предусматривает административную ответственность за воспрепятствование организации или проведению собрания, митинга, демонстрации, шествия или пикетирования, проводимых в соответствии с законодательством Российской Федерации, либо участию в них, а равно принуждение к участию в них.

В настоящее время в ст. 20.2. КоАП РФ предусмотрена административная ответственность за нарушение установленного порядка организации собрания, митинга, демонстрации, шествия или пикетирования. Нарушение организатором публичного мероприятия установленного порядка организации либо проведения собрания, митинга, демонстрации, шествия или пикетирования.

Организация либо проведение публичного мероприятия без подачи в установленном порядка уведомления о проведении публичного мероприятия, за исключением случаев, предусмотренных законом. К организации публичного мероприятия относятся: оповещение возможных участников публичного мероприятия и подача уведомления о проведении публичного мероприятия в соответствующий орган исполнительной власти субъекта Российской Федерации или орган местного самоуправления; проведение предварительной агитации; изготовление и распростране- 
ние средств наглядной агитации; другие действия, не противоречащие законодательству Российской Федерации, совершаемые в целях подготовки и проведения публичного мероприятия.

Действия (бездействие), повлекшие создание помех движению пешеходов или транспортных средств либо превышение норм предельной заполняемости территории (помещения). Действия (бездействие), предусмотренные КоАП РФ, повлекшие причинение вреда здоровью человека или имуществу, если эти действия (бездействие) не содержат уголовно наказуемого деяния.

Нарушение участником публичного мероприятия установленного порядка проведения собрания, митинга, демонстрации, шествия или пикетирования, за исключением случаев, предусмотренных законом. Действия (бездействие), повлекшие причинение вреда здоровью человека или имуществу, если эти действия (бездействие) не содержат уголовно наказуемого деяния.

Организация либо проведение несанкционированных собрания, митинга, демонстрации, шествия или пикетирования в непосредственной близости от территории ядерной установки, радиационного источника или пункта хранения ядерных материалов и радиоактивных веществ либо активное участие в таких публичных мероприятиях, если это осложнило выполнение работниками указанных установки, источника или пункта своих служебных обязанностей или создало угрозу безопасности населения и окружающей среды.

Федеральный закон от 19 июня 2004 г. «О собраниях, митингах, демонстрациях, шествиях и пикетированиях» ${ }^{44}$ определяет места, в которых проведение публичного мероприятия запрещается. К таким местам относятся: территории, непосредственно прилегающие к опасным производствен-

${ }^{44}$ См.: Собрание законодательства РФ. - 2004. - № 25. Ст. 2485. ным объектам и к иным объектам, эксплуатация которых требует соблюдения специальных правил техники безопасности; путепроводы, железнодорожные магистрали и полосы отвода железных дорог, нефте-, газо- и продуктопроводов, высоковольтных линий электропередачи; территории, непосредственно прилегающие к резиденциям Президента Российской Федерации, к зданиям, занимаемым судами, к территориям и зданиям учреждений, исполняющих наказание в виде лишения свободы; пограничная зона, если отсутствует специальное разрешение уполномоченных на то пограничных органов.

Законодательные, организационные и иные меры, предпринимаемые органами публичной власти в целях надлежащего обеспечения права на свободу мирных собраний, не должны приводить к чрезмерному государственному контролю за деятельностью организаторов и участников публичных мероприятий, сопряженному с необоснованными ограничениями свободного проведения собраний, митингов и демонстраций, шествий и пикетирования. Вместе с тем, принимая во внимание природу гарантированного ст. 31 Конституции Российской Федерации права, предполагающую исключительно мирный способ выражения гражданами своих взглядов и их доведения до соответствующих адресатов, в случаях, когда организаторы или участники публичного мероприятия ведут себя деструктивно, в частности явно намереваются совершить или, более того, совершают какие-либо действия, угрожающие общественному порядку и (или) общественной безопасности, государство - во исполнение своей конституционной обязанности по защите прав и свобод человека и гражданина - должно использовать для недопущения и пресечения проявлений, не отвечающих существу права на мирные собрания, все законные средства.

Таким образом, гарантированное Конституцией Российской Федерации и на- 


\section{Полицейская деятельность 2 • 2014}

званными международно-правовыми актами как составной частью правовой системы Российской Федерации (статья 15, ч. 4 Конституции Российской Федерации) право граждан Российской Федерации собираться мирно, без оружия, проводить собрания, митинги и демонстрации, шествия и пикетирование не является абсолютным и может быть ограничено федеральным законом в целях защиты конституционно значимых ценностей при обязательном соблюдении принципов необходимости, пропорциональности и соразмерности, с тем чтобы вводимые им ограничения не посягали на само существо данного конституционного права и не препятствовали открытому и свободному выражению гражданами своих взглядов, мнений и требований посредством организации и проведения мирных публичных акций. Соответственно, такой федеральный закон должен обеспечивать возможность полноценной реализации права на свободу мирных собраний и одновременно - соблюдение надлежащего общественного порядка и безопасности без ущерба для здоровья и нравственности граждан на основе баланса интересов организаторов и участников публичных мероприятий, с одной стороны, и третьих лиц - с другой, исходя из необходимости государственной защиты прав и свобод всех лиц (как участвующих, так и не участвующих в публичном мероприятии), в том числе путем введения адекватных мер предупреждения и предотвращения нарушений общественного порядка и безопасности, прав и свобод граждан, а также установления эффективной публично-правовой ответственности за действия, их нарушающие или создающие угрозу их нарушения.

\section{Библиография:}

1. Алоян А.М., Эглит В.И. Правовое регулирование охраны общественного порядка при проведении 15 массовых мероприятий // Административно-правовые проблемы охраны общественного порядка.-М., 1987.

2. Балтага Д.А. Политические свободы собраний, митингов, уличных шествий и демонстраций и их реализация в деятельности органов внутренних дел: Дис. ... канд. юрид. наук.-М., 1993.

3. Веремеенко И., Воробьев В., Якимов А. Митинги, демонстрации, собрания // Социалистическая законность.-1989.-№ 6.

4. Евтихиев А.Ф. Основы советского административного права.-Харьков, 1925.

5. Дмитриев Ю.А. Свобода манифестаций в СССР.-М., 1991.

6. Караханов Н.В. Управление горрайорганами внутренних дел при проведении массовых мероприятий.-М., 1992.

7. Коптев Н.В. Административно-правовая охрана порядка организации и проведения публичных мероприятий: Дис. ... канд. юрид. наук.-М., 2001.

8. Нечевин Д.К. Организация деятельности органов внутренних дел по обеспечению правопорядка при проведении массовых мероприятий // Предупреждение преступности и обеспечение безопасности в городах.-М., 2001.

9. Огурцов Н.А., Наумов А.В. Понятие уголовной ответственности // Труды Высшей следственной школы МВД СССР. - Волгоград, 1969.

10. Полянская И.С. Конституционно-правовое регулирование права граждан Российской Федерации на проведение собраний, митингов и демонстраций, шествий и пикетирования: Автореф. дис. ... канд. юрид. наук. - М., 2005.

11. Рыбаков В.А. Позитивная юридическая ответственность (воспитательные аспекты). - Рязань, 1988. 
12. Юридическая психология / Под ред. Ю.В Чуфаровского. - М., 1998.

13. Куракин А.В. Компетенция полиции в сфере реализации законодательства об административных правонарушениях // NB: Административное право и практика администрирования. - 2013. - 4. - C. 28 - 48. DOI: 10.7256/2306-9945.2013.4.8841. URL: http://www.e-notabene. ru/al/article_8841.html

14. Костенников М.В., Куракин А.В., Трегубова Е.В. Конституционное право на проведение мирных собраний, митингов, демонстраций, шествий и пикетирования и административная ответственность как средство его обеспечения // NB: Административное право и практика администрирования. - 2013. - 8. - C. 82 - 105. DOI: 10.7256/2306-9945.2013.8.9955. URL: http://www.e-notabene.ru/al/article_9955.html

15. Куракин А.В., Бадулин А.Д., Трегубова Е.В. Административная ответственность за правонарушения на рынке алкоголя и роль полиции в ее реализации // NB: Административное право и практика администрирования. - 2013. - 10. - C. 28 - 74. DOI: 10.7256/23069945.2013.10.10151. URL: http://www.e-notabene.ru/al/article_10151.html

16. Куракин А.В. Компетенция полиции в сфере реализации законодательства об административных правонарушениях // Административное и муниципальное право. - 2013. - 6. C. 624 - 630. DOI: 10.7256/1999-2807.2013.06.5.

17. Трегубова Е.В. Административные запреты в сфере осуществления полицейской деятельности // NB: Российское полицейское право. - 2013. - 1. - С. 25 - 44. DOI: 10.7256/23064218.2013.1.718. URL: http://www.e-notabene.ru/pm/article_718.html

18. Костенников М.В., Куракин А.В. К вопросу об основании административной ответственности в российском праве // NB: Административное право и практика администрирования. 2013. - 10. - C. 75 - 88. DOI: 10.7256/2306-9945.2013.10.10153. URL: http://www.e-notabene. ru/al/article_10153.html

19. Куракин А.В., Костенников М.В. Принципы организации и деятельности российской полиции // NB: Российское полицейское право. - 2013. - 2. - С. 22 - 49. DOI: 10.7256/23064218.2013.2.799. URL: http://www.e-notabene.ru/pm/article_799.html

\section{References (transliteration):}

1. Aloyan A.M., Eglit V.I. Pravovoe regulirovanie okhrany obshchestvennogo poryadka pri provedenii 15 massovykh meropriyatii // Administrativno-pravovye problemy okhrany obshchestvennogo poryadka.-M., 1987.

2. Baltaga D.A. Politicheskie svobody sobranii, mitingov, ulichnykh shestvii i demonstratsii i ikh realizatsiya $v$ deyatel'nosti organov vnutrennikh del: Dis. ... kand. yurid. nauk.-M., 1993.

3. Veremeenko I., Vorob'ev V., Yakimov A. Mitingi, demonstratsii, sobraniya // Sotsialisticheskaya zakonnost'.-1989.-№ 6.

4. Evtikhiev A.F. Osnovy sovetskogo administrativnogo prava.-Khar'kov, 1925.

5. Dmitriev Yu.A. Svoboda manifestatsii v SSSR.-M., 1991.

6. Karakhanov N.V. Upravlenie gorraiorganami vnutrennikh del pri provedenii massovykh meropriyatii.-M., 1992.

7. Koptev N.V. Administrativno-pravovaya okhrana poryadka organizatsii i provedeniya publichnykh meropriyatii: Dis. ... kand. yurid. nauk.-M., 2001.

8. Nechevin D.K. Organizatsiya deyatel'nosti organov vnutrennikh del po obespecheniyu pravoporyadka pri provedenii massovykh meropriyatii // Preduprezhdenie prestupnosti i obespechenie bezopasnosti v gorodakh.-M., 2001. 


\section{Полицейская деятельность 2 • 2014}

9. Ogurtsov N.A., Naumov A.V. Ponyatie ugolovnoi otvetstvennosti // Trudy Vysshei sledstvennoi shkoly MVD SSSR. - Volgograd, 1969.

10. Polyanskaya I.S. Konstitutsionno-pravovoe regulirovanie prava grazhdan Rossiiskoi Federatsii na provedenie sobranii, mitingov i demonstratsii, shestvii i piketirovaniya: Avtoref. dis. ... kand. yurid. nauk.-M., 2005.

11. Rybakov V.A. Pozitivnaya yuridicheskaya otvetstvennost' (vospitatel'nye aspekty). - Ryazan', 1988.

12. Kurakin A.V. Kompetentsiya politsii v sfere realizatsii zakonodatel'stva ob administrativnykh pravonarusheniyakh // NB: Administrativnoe pravo i praktika administrirovaniya. - 2013. 4. - C. 28 - 48. DOI: 10.7256/2306-9945.2013.4.8841. URL: http://www.e-notabene.ru/al/article_8841.html

13. Kostennikov M.V., Kurakin A.V., Tregubova E.V. Konstitutsionnoe pravo na provedenie mirnykh sobranii, mitingov, demonstratsii, shestvii i piketirovaniya i administrativnaya otvetstvennost' kak sredstvo ego obespecheniya // NB: Administrativnoe pravo i praktika administrirovaniya. - 2013. - 8. - C. 82 - 105. DOI: 10.7256/2306-9945.2013.8.9955. URL: http://www.e-notabene.ru/al/ article_9955.html

14. Kurakin A.V., Badulin A.D., Tregubova E.V. Administrativnaya otvetstvennost' za pravonarusheniya na rynke alkogolya i rol' politsii $v$ ee realizatsii // NB: Administrativnoe pravo i praktika administrirovaniya. - 2013. - 10. - C. 28 - 74. DOI: 10.7256/2306-9945.2013.10.10151. URL: http://www.e-notabene.ru/al/article_10151.html

15. Kurakin A.V. Kompetentsiya politsii v sfere realizatsii zakonodatel'stva ob administrativnykh pravonarusheniyakh // Administrativnoe i munitsipal'noe pravo. - 2013. - 6. - C. 624 - 630. DOI: 10.7256/1999-2807.2013.06.5.

16. Tregubova E.V. Administrativnye zaprety v sfere osushchestvleniya politseiskoi deyatel'nosti // NB: Rossiiskoe politseiskoe pravo. -2013. -1. - C. 25-44. DOI: 10.7256/2306-4218.2013.1.718. URL: http://www.e-notabene.ru/pm/article_718.html

17. Kostennikov M.V., Kurakin A.V. K voprosu ob osnovanii administrativnoi otvetstvennosti v rossiiskom prave // NB: Administrativnoe pravo i praktika administrirovaniya. - 2013. - 10. - C. 75 - 88. DOI: 10.7256/2306-9945.2013.10.10153. URL: http://www.e-notabene.ru/al/article_10153.html

18. Kurakin A.V., Kostennikov M.V. Printsipy organizatsii i deyatel'nosti rossiiskoi politsii // NB: Rossiiskoe politseiskoe pravo. - 2013. - 2. - C. 22 - 49. DOI: 10.7256/2306-4218.2013.2.799. URL: http://www.e-notabene.ru/pm/article_799.html 